\title{
RESTRICTED SELECTION INDICES IN SUGARCANE (SACCHARUM OFFICINARUM L.)
}

\section{G. VINAY KUMAR \& V. SATYANARAYANA RAO}

Agricultural College, Bapatla, Guntur, Andhra Pradesh, India

\begin{abstract}
An investigation was conducted at the Sugarcane Research Station, Vuyyuru, Krishna District, Andhra Pradesh, India to carry out Restricted Selection indices among twelve component characters of sugarcane viz., Numbers of Germinants at 35 DAP, Stalk Population at 240 DAP, Number of Millable canes, Length of millable cane (cm), Diameter of millable cane (cm), Single cane weight $(\mathrm{kg})$, Cane yield (kg/plot), CCS yield (kg/plot), Brix per cent, Per cent sucrose, purity per cent, and CCS per cent.The genetic advance of all the twelve characters under study was estimated by assigning equal economic weights to all characters. Single case restricted selection was carried out by restricting the selection for only eleven out of twelve characters without affecting any change in the twelveth character. In all such twelve possible restriction selections, the character brix per cent recorded highest estimate of genetic advance in all cases except when sucrose per cent, purity per cent and cane yield are not considered in their respective single case restriction selection indices. In such case, single cane weight recorded highest estimate of genetic advance.
\end{abstract}

KEYWORDS: Restriction Selection Indices, Genetic Advance, Economic Weight and Sugarcane

Received: Jun 15, 2017; Accepted: Jun 30, 2017; Published: Jul 05, 2017; Paper Id.: IJASRAUG201716

\section{INTRODUCTION}

Sugarcane is an important cash crop in India and one of the most important agro industrial crops of the world. It assumes an important position in the economy of the country. Sugarcane production is 330.36 MMT in 2016-17 in India and its average yield is 70.07 MT/ha (Sugar Annual India, 2016). Complex traits like cane yield and quality are influenced by a number of characters. These characters directly and indirectly contribute to the yield. An understanding of cane yield, sugar yield and interrelationships among other component traits with economic yield is also important to adopt an appropriate breeding strategy. Cane yield is a highly complex quantitative character influenced by several component characters and hence direct selection may not be reliable. Under certain situations, the breeder might like to effect change in means of some characters while keeping the means of other characters unchanged. To enable this kind of selection Kempthrone and Nordskog (1959) introduced the concept of "restricted selection indices" which enables us to restrict change in only some characters without affecting the development in other characters.

\section{MATERIAL AND METHODS}

The experimental material for the present study consisted of 13 clones of sugarcane including 11 early maturing clones and two standards viz., Co 6907 and 87 A 298. The experiment opted randomized block design with three replications, each genotype planted in eight rows( $80 \mathrm{~cm}$ apart) and each row having about eight-meter length with a net plot size of $38.4 \mathrm{~m}^{2}$ ( 6 rows $\times 8 \mathrm{~m} \times 0.8 \mathrm{~m}$ ). The sets having three eye buds each was planted with four sets 
per meter. The crop received $168 \mathrm{~kg} \mathrm{~N}, 75 \mathrm{~kg} \mathrm{P}_{2} \mathrm{O}_{5}$ and $100 \mathrm{~kg} \mathrm{~K}_{2} \mathrm{O} /$ hectare. All the recommended package of practices was adopted during the entire crop season. Observations were recorded on net plot basis viz., number of Germinants at 35 DAP, Number of millable canes and Cane yield ( $\mathrm{t} / \mathrm{ha}$ ). Sugar yield ( $\mathrm{t} / \mathrm{ha}$ ) was estimated based on cane yield and CCS per cent. Data on Length of millable cane, diameter of millable cane and single cane weight were recorded on 10 randomly selected canes in each plot and replication at harvest. Juice quality parameters such as Brix per cent, sucrose per cent, purity per cent and CCS per cent were also estimated. Among the twelve characters taken in the present study, selection was restricted to only eleven characters at a time without changing the mean of remaining twelfth character. And all such twelve possible cases were worked out according to Singh and Chaudhary (1977) and the genetic advances for eleven characters subjected to selection in each of the twelve cases were estimated.

\section{RESULTS AND DISCUSSIONS}

The estimates of genetic advances of all the twelve characters in each of the thirteen cases, when equal economic weights were assigned are presented in the table 1.

In the first case when selection is restricted to eleven characters without affecting the mean of Germination count at $35 \mathrm{DAP}$, the highest estimate of genetic advance was recorded in case of brix per cent (102.8) followed by the diameter of the cane (62.62) and single cane weight (53.76) while the least estimate was observed for sucrose per cent (-92.34).

In the second case when selection is restricted to eleven characters leaving Stalk population at 240 DAP, the highest estimate of genetic advance was recorded by Brix per cent (84.08) followed by single cane weight (70.78) and CCS yield (kg/plot) (27.38) while the least value was observed in sucrose per cent (-135.67).

In the third case where Number of millable cane is not considered for selection, the highest estimate of genetic advance was recorded by Brix per cent (147.86) followed by single cane weight (125.96) and CCSper cent (64.41) while the least value was observed in sucrose per cent (-205.93).

In the fourth case when selection is restricted to eleven characters without affecting Length of millable cane , the highest estimate of genetic advance was recorded in case of brix per cent (187.07) followed by single cane weight (72.63) and CCS per cent (61.62) while the least value was observed for sucrose per cent (-190.94).

In the fifth case when selection is imposed on the combination of eleven characters which does not include Cane diameter, the highest estimate of genetic advance was recorded in case of brix per cent (142.95) followed by single cane weight (73.35) while the least value was observed for sucrose per cent (-185.19).

In the sixth case when selection is restricted to the combination of eleven characters which does not include Single cane weight, the highest estimate of genetic advance was recorded in case of brix per cent (142.87) followed by purity per cent (20.25) while the least value was observed for sucrose per cent (-184.63).

In the seventh case when selection is restricted to the combination of eleven characters which does not include brix per cent, the highest estimate of genetic advance was recorded in case of single cane weight (122.65) followed by CCS yield (kg/plot) (23.84) while the least estimate was observed for diameter of millable cane (-99.30).

In the eight cases where sucrose per cent is not considered for selection, the highest estimate of genetic advance was recorded by single cane weight (101.26) followed by CCS yield (kg/plot) (20.65) while the least estimate was observed for the diameter of millable cane (-66.26). 
In the ninth case when selection is restricted to the combination of eleven characters which does not include purity percent, the highest estimate of genetic advance was recorded by sucrose percent (145.48) followed by single cane weight (121.75) and Brix (66.02) per cent while the least value was observed for Cane diameter (-93.62).

In the tenth case where CCS per cent is not considered for selection, the highest estimate of genetic advance was recorded by Brix per cent (127.15) followed by single cane weight (103.23) while the least value was observed in sucrose per cent (-185.50).

In the eleventh case when selection is restricted to the combination of eleven characters which does not include cane yield (kg/plot), the highest estimate of genetic advance was recorded by Single cane weight (kg) (100.05) followed by CCS per cent (95.32) and Brix per cent (65.59) while the least value was observed for sucrose per cent (-130.70).

In the twelve cases where CCS yield (kg/plot) is not considered for selection, the highest estimate of genetic advance was recorded by Brix per cent (121.81) followed by single cane weight (99.57) and CCS per cent (85.74) while the least value was observed in sucrose per cent $(-182.25)$.

\section{CONCLUSIONS}

In all the above twelve cases of restricted selections, the character brix per cent recorded highest estimate of genetic advance in all cases except when sucrose per cent, purity percent and cane yield (kg/plot) were not consider for selection (Table 1), where single cane weight at harvest recorded highest estimate of genetic advance. Lower values of genetic advance were observed in case of sucrose per cent in all cases except when Brix per cent and purity percent were considered in single cases restricted selection indices, where single cane weight recorded low estimate of genetic advance.

Hence, improvement can be anticipated in all the characters which are showing highest genetic advance values by restricting a particular individual character. Similar conclusions were drawn by Sireesha (2009).

\section{REFERENCES}

1. Kempthorne, $O$ and Nordskog, A.W. 1959. Restricted selection indices. Biometrics. 15: 10-15.

2. Singh, R.K and Chaudhary, B.D. 2010. Biometrical Methods in Quantitative Genetic Analysis. Kalyani publishers, New Delhi.pp: 293-301.

3. Sireesha, M. 2009. Character Association, Path Analysis and Selection Indices in Sugarcane ( Saccharum officinarum L.). M.Sc (Ag) Thesis. Acharya N.G. Ranga Agricultural University, Hyderabad.

4. Sugar Annual India, 2016.https://gain.fas.usda.gov. 


\section{APPENDICES}

Table 1: Genetic Advance ( $\Delta G \mathbf{G})$ Values in Case of Single Case Restricted Selection Indices in 13 Genotypes of Sugarcane (Saccharum officinarum L.)

\begin{tabular}{|c|c|c|c|c|c|c|c|c|c|c|c|c|}
\hline Character & $\begin{array}{l}\text { Number of } \\
\text { Germinants } \\
\text { at } 35 \mathrm{DAP}\end{array}$ & $\begin{array}{c}\text { Stalk } \\
\text { Population } \\
\text { at 240 DAP }\end{array}$ & $\begin{array}{c}\text { Number of } \\
\text { Millable } \\
\text { Canes }\end{array}$ & $\begin{array}{c}\text { Length of } \\
\text { Millable } \\
\text { Cane } \\
\end{array}$ & $\begin{array}{c}\text { Diameter of } \\
\text { Millable } \\
\text { Cane }\end{array}$ & $\begin{array}{c}\text { Single Cane } \\
\text { Weight }\end{array}$ & Brix Per Cent & $\begin{array}{l}\text { Sucrose } \\
\text { per cent }\end{array}$ & $\begin{array}{c}\text { Purity } \\
\text { Per Cent }\end{array}$ & $\begin{array}{c}\text { CCS per } \\
\text { Cent }\end{array}$ & $\begin{array}{c}\text { Cane } \\
\text { Yield } \\
\text { (kg/plot) }\end{array}$ & $\begin{array}{c}\text { CCS } \\
\text { Yield } \\
(\mathrm{kg} / \text { Plot })\end{array}$ \\
\hline $\begin{array}{l}\text { Number of } \\
\text { Germinants at } 35 \\
\text { DAP/plot }\end{array}$ & 0.00 & 0.533 & 1.10 & 0.727 & 62.62 & 53.76 & 102.08 & .92 .34 & 20.62 & 20.86 & 2.46 & -11.10 \\
\hline $\begin{array}{l}\text { Stalkpopulation at } \\
240 \mathrm{DAP} / \text { plot }\end{array}$ & 0.22 & 0.00 & 1.25 & 2.46 & -100.68 & 70.78 & 84.08 & .135 .67 & 6.52 & $\cdot 17.59$ & -2.63 & 27.38 \\
\hline $\begin{array}{l}\text { Number of millable } \\
\text { canes }\end{array}$ & 0.14 & 0.913 & 0.00 & 1.82 & .79 .01 & 125.96 & 147.86 & -205.93 & 19.52 & 64.41 & 0.114 & 6.14 \\
\hline $\begin{array}{l}\text { Length of millable } \\
\text { cane }\end{array}$ & 0.24 & 0.67 & 1.19 & 0.00 & 58.04 & 72.63 & 187.07 & $\cdot 190.94$ & 31.73 & 61.62 & 2.71 & .13 .31 \\
\hline $\begin{array}{l}\begin{array}{l}\text { Diameter of } \\
\text { millable cane }\end{array} \\
\end{array}$ & 0.23 & 0.67 & 1.39 & 1.99 & 0.00 & 73.35 & 142.95 & .185 .19 & 19.59 & 22.63 & -0.49 & 10.80 \\
\hline Single cane weight & 0.22 & 0.68 & 1.48 & 2.27 & .22 .63 & 0.00 & 142.87 & .184 .63 & 20.25 & -3.68 & -1.39 & 18.67 \\
\hline Brix per cent & 0.28 & 0.67 & 1.43 & 2.64 & .99 .30 & 122.65 & 0.00 & .71 .77 & -11.34 & 20.46 & -2.35 & 23.84 \\
\hline Sucroseper cent & 0.32 & 0.65 & 1.45 & 2.38 & .66 .26 & 101.26 & -8.31 & 0.00 & -8.72 & -47.92 & -1.87 & 20.65 \\
\hline Purityper cent & 0.25 & 0.67 & 1.43 & 2.50 & .93 .62 & 121.75 & 66.02 & 145.48 & 0.00 & 32.97 & -2.13 & 22.44 \\
\hline CCS per cent & 0.24 & 0.69 & 1.43 & 2.31 & .70 .20 & 103.23 & 127.15 & .185 .50 & 14.94 & 0.00 & -2.06 & 22.50 \\
\hline $\begin{array}{l}\text { Caneyield } \\
\text { (Kgplot) }\end{array}$ & 0.40 & 0.62 & 1.21 & 1.47 & -45.21 & 100.05 & 65.59 & $\cdot 130,70$ & 4.48 & 95.32 & 0.00 & -0.27 \\
\hline CCS yield (kg $\mathrm{kglot})$ & 0.21 & 0.66 & 1.30 & 1.97 & .37 .61 & 99.57 & 121.81 & .182 .25 & 14.43 & 85.74 & 0.70 & 0.00 \\
\hline
\end{tabular}

